\title{
Anti-receptor activator nuclear factor $\kappa-B$ ligand (anti- RANKL) as an antiresorptive agent for renal failure osteoporotic patient
}

\author{
Mansoor Karimifar ${ }^{*}$, Mozhgan Karimifar ${ }^{2}$
}

$\mathrm{O}$ steoporosis is one of the challenges of today's world. Bones, like other organs of the body, become aging and are aggravated by the aging process. Treatment for osteoporosis is difficult in people without underlying illness and in patients with underlying illness is much more difficult. One of the most important underlying conditions that cause secondary osteoporosis is renal failure. Treatment for renal failure, especially those who undergo dialysis, is also very difficult and challenging. Bisphosphonates have been administered for the treatment of osteoporosis for many years, but they are used with caution in those who have renal failure. With the introduction of Prolia as an anti-osteoporosis drug, the hope was created to treat patients with kidney failure (1-3).

Denosumab (Prolia) is a human IgG2 monoclonal antibody with attraction and specificity for human receptor activator of nuclear factor kappa-B ligand (RANKL). Denosumab has an approximate molecular weight of $147 \mathrm{kDa}$ and is constructed in genetically engineered mammalian, administered subcutaneously every 6 months. It reduces the risk of vertebral fracture by $70 \%$ and of hip fracture by $40 \%$. Denosumab may be administered to treat individuals with moderate to severe kidney failure (1). RANKL produces by osteoblasts cells and causes bone matrix degradation. Denosumab acts by trapping RANKL causes its neutralization. One important side effect is hypocalcemia, which may be life threatening. The risk of this is increased in renal impairment, mainly if glomerular filtration rate (GFR) $<30 \mathrm{~mL} / \mathrm{min}$. Hypocalcemia is also exacerbated by vitamin D insufficiency (2). Additionally, adynamic bone disease is a contraindication for this drug. If there is any doubt, bone biopsy should be conducted (4).

\section{Authors' contribution}

MK and MK wrote the manuscript equally.

Conflicts of interest

The authors declare no conflicting interest.

\begin{abstract}
Implication for health policy/practice/research/ medical education

Treatment for renal failure, especially those who undergo dialysis, is very difficult and challenging. Bisphosphonates have been administered for the treatment of osteoporosis for many years, but they are administered with caution in those who have renal failure. With the introduction of Prolia as an anti-osteoporosis drug, the hope was created to treat patients with kidney failure.
\end{abstract}

Keywords: Osteoporosis, Renal failure, Vitamin D, Osteoblasts

\section{Ethical considerations}

Ethical issues (including plagiarism, data fabrication, double publication) have been completely observed by the authors.

\section{Funding/Support}

None.

\section{References}

1. Diédhiou D, Cuny T, Sarr A, Norou Diop S, Klein M, Weryha G. Efficacy and safety of denosumab for the treatment of osteoporosis: A systematic review. Ann Endocrinol (Paris). 2015;76:650-7. doi: 10.1016/j.ando.2015.10.009.

2. Blackley S1, Anderson K, Berg J. A case of denosumabinduced hypocalcaemia in a patient with non-metastatic prostate cancer and renal impairment. J R Coll Physicians Edinb. 2015;45:133-5. doi: 10.4997/JRCPE.2015.209.

3. VA/NIH Acute Renal Failure Trial Network. Intensity of renal support in critically ill patients with acute kidney injury. N Engl J Med. 2008;359:7-20

4. Schipper LG, Fleuren HW, van den Bergh JP, Meinardi JR, Veldman BA, Kramers C. Treatment of osteoporosis in renal insufficiency. Clin Rheumatol. 2015;34:1341-5. doi: 10.1007/s10067-015-2883-4.

\footnotetext{
Please cite this paper as: Karimifar M, Karimifar M. Anti-receptor activator nuclear factor $\kappa-B$ ligand (anti-RANKL) as an antiresorptive agent for renal failure osteoporotic patient. J Parathyr Dis. 2018;6(2):33. DOI: 10.15171/jpd.2018.12.

Copyright (c) 2018 The Author(s); Published by Nickan Research Institute. This is an open-access article distributed under the terms of the Creative Commons Attribution License, which permits unrestricted use, distribution, and reproduction in any medium, provided the original work is properly cited.
} 